\title{
Hematological changes associated with hemoplasma infection in cats in Rio de Janeiro, Brazil
}

\author{
Alterações hematológicas associadas à infecção por hemoplasmas em gatos do Rio de Janeiro, Brasil \\ Juliana Macedo Raimundo ${ }^{1}$; Andresa Guimarães ${ }^{1}$; Raisa Braul Rodrigues ${ }^{1}$; Camila Flávia Magalhães Botelho ${ }^{1}$; \\ Maristela Peckel Peixoto ${ }^{2}$; Marcus Sandes Pires ${ }^{2}$; Carlos Henrique Machado ${ }^{1}$; Huarrisson Azevedo Santos ${ }^{3}$; \\ Carlos Luiz Massard ${ }^{2}$; Marcos Rogério André ${ }^{4}$; Rosangela Zacarias Machado ${ }^{4}$; Cristiane Divan Baldani ${ }^{1 *}$

\footnotetext{
${ }^{1}$ Laboratório de Patologia Clínica Veterinária, Departamento de Medicina e Cirurgia Veterinária, Instituto de Veterinária, Universidade Federal Rural do Rio de Janeiro - UFRRJ, Seropédica, RJ, Brasil

${ }^{2}$ Laboratório de Hemoparasitos e Vetores, Departamento de Parasitologia Animal, Instituto de Veterinária, Universidade Federal Rural do Rio de Janeiro - UFRRJ, Seropédica, RJ, Brasil

${ }^{3}$ Laboratório de Sanidade Avícola, Departamento de Epidemiologia e Saúde Pública, Instituto de Veterinária, Universidade Federal Rural do Rio de Janeiro - UFRRJ, Seropédica, RJ, Brasil

${ }^{4}$ Laboratório de Imunoparasitologia, Departamento de Patologia Veterinária, Faculdade de Ciências Agrárias e Veterinárias, Universidade Estadual Paulista - UNESP, Jaboticabal, SP, Brasil
}

Received August 12, 2016

Accepted October 26, 2016

\begin{abstract}
This study aimed to detect Mycoplasma spp. in naturally infected cats from Rio de Janeiro and to evaluate hematological abnormalities and factors associated with this infection. Out of the 197 cats sampled, $11.2 \%$ presented structures compatible with hemoplasma organisms on blood smears. In contrast, $22.8 \%$ were positive for Mycoplasma spp. by means of $16 \mathrm{~S} \mathrm{rRNA}$ gene real-time polymerase chain reaction, which reflects the weak concordance between techniques. The infection rates, by means of 16S rRNA gene conventional polymerase chain reaction, was 4.6\%, 4.6\% and 11.7\% for Mycoplasma haemofelis (Mhf), 'Candidatus Mycoplasma turicensis' (CMt) and 'Candidatus Mycoplasma haemominutum' (CMhm), respectively. Mhf and CMhm infections are more frequent in the summer $(\mathrm{p}>0.05)$. Presence of anemia $(\mathrm{p}<0.02)$, lymphocytosis $(\mathrm{p}<0.03)$, thrombocytopenia $(\mathrm{p}<0.04)$ and activated monocytes $(\mathrm{p}<0.04)$ was associated with Mhf infection. No hematological abnormality was associated with CMt or CMhm infection. Male cats were more prone to be infected by Mhf or CMhm ( $\mathrm{p}$ 0.01). Adult cats had more chance to be infected by CMhm. Three hemoplasma species occur in the metropolitan region of Rio de Janeiro and Mhf seems to be the most pathogenic of them. Anemia is the most important hematological abnormality.
\end{abstract}

Keywords: Mycoplasma spp., real-time PCR, hematology, associated factors.

\section{Resumo}

Este estudo teve por objetivo detectar Mycoplasma spp. em gatos naturalmente infectados do Rio de Janeiro e avaliar as alteraçóes hematológicas e fatores associados à infecção. Dos 197 gatos amostrados, 11,2\% apresentaram estruturas compatíveis com hemoplasmas em esfregaços de sangue. Em contraste, 22,8\% foram positivas para Mycoplasma spp. por meio da reação em cadeia da polimerase em tempo real (qPCR), baseado no gene 16S rRNA, o que reflete a fraca concordância entre as técnicas. As taxas de infecção, por meio da reação em cadeia da polimerase convencional baseada no gene 16S rRNA, foi de 4,6\%, 4,6\% e 11,7\% para Mycoplasma haemofelis (Mhf), 'Candidatus Mycoplasma turicensis' (CMt) e 'Candidatus Mycoplasma haemominutum' (CMhm), respectivamente. Infecção por Mhf e CMhm foram mais frequentes no verão $(p>0,05)$. Anemia $(p<0,02)$, linfocitose $(p<0,03)$, trombocitopenia $(p<0,04)$, e presença de monócitos ativados $(p<0,04)$ foram associados à infecção por Mhf. Nenhuma alteração hematológica foi associada à infecção por CMt ou CMhm. Gatos machos estão mais propensos à infecção por Mhf ou CMhm $(\mathrm{p}<0,01)$. Gatos adultos têm maiores chances de se infectarem por CMhm. Há ocorrência de três espécies de hemoplasmas na Região Metropolitana do Rio de Janeiro e Mhf parece ser o mais patogênico, tendo a anemia como principal alteração hematológica.

Palavras-chave: Mycoplasma spp., PCR em tempo real, hematologia, fatores associados.

*Corresponding author: Cristiane Divan Baldani. Laboratório de Patologia Clínica Veterinária, Departamento de Medicina e Cirurgia Veterinária, Instituto de Veterinária, Universidade Federal Rural do Rio de Janeiro - UFRRJ, BR 465, Km 47, CEP 23890-000, Seropédica, RJ, Brasil. e-mail: crisbaldani@ufrrj.br 


\section{Introduction}

Hemotropic mycoplasmas are obligate Gram-negative bacteria that infect the surface of red blood cells (TASKER, 2010). These microorganisms infect a wide range of hosts including cats, dogs, pigs and humans (WENGI et al., 2008; HU et al., 2009; SYKES, 2010; MAGGI et al., 2013). Mycoplasma haemofelis, 'Candidatus Mycoplasma haemominutum' and/or 'Candidatus Mycoplasma turicensis' infection are important causes of anemia in cats. These bacteria can be transmitted between cats through blood transfusions, vertical transmission, social interactions via fighting and cat flea bites (Ctenocephalides felis). Infected cats can demonstrate mild to severe anemia or even be asymptomatic. The clinical signs and laboratory abnormalities of hemoplasmosis are variable. The clinical signs that are most often exhibited include mucosal pallor, lethargy, dehydration, inappetence, weight loss, weakness, tachypnea, tachycardia and occasionally pyrexia and jaundice. Regenerative anemia with anisocytosis, polychromasia, reticulocytosis and Howell-Jolly bodies are the hematological changes most commonly observed in infected cats (TASKER, 2010). There are two possible mechanisms for occurrences of anemia: direct damage to the erythrocyte membrane by the organism; or immune mediation, thus resulting in declining numbers of red blood cells due to hemolysis (VILLIERS, 2005; TASKER, 2010). Feline hemoplasma infection has been often associated with male cats with outdoor access and adults cats (SYKES, 2010; TASKER, 2010)

Although blood smear analysis is commonly used for diagnosing hemoplasmas in cats, use of molecular assays as an alternative diagnostic tool has increased the sensitivity of pathogen detection in different cat populations. Their high sensitivity and specificity have made it possible to differentiate Mycoplasma species and to detect them in asymptomatic cats (SYKES, 2010; TASKER, 2006). The real-time polymerase chain reaction (PCR) test has been applied for this purpose because of its higher sensitivity for screening apparent healthy cats, for them to become blood donors and to be introduced into pathogen-free colonies, so as to quantify bacterial DNA in biological samples and hence monitor the response to treatment (BRADDOCK et al., 2004; TASKER, 2010; MARTÍNEZ-DÍAZ et al., 2013).

The aims of the present study were to use molecular techniques to detect hemoplasma infection in cats in the metropolitan region of Rio de Janeiro, and to establish the correlation between this infection and hematological data and associated factors. In addition, this work also intended to compare cytological and molecular methods used to identify Mycoplasma spp. and to determine influence of season on hemoplasmas infection in cats.

\section{Materials and Methods}

\section{Sampled animals and data}

The study was conducted in the metropolitan region of the state of Rio de Janeiro, Brazil, including the municipalities of Belford Roxo (220 45' 51" S; 43 23' 58” W), Duque de Caxias (22。 47’ 08” S; $\left.43^{\circ} 18^{\prime} 42^{\prime \prime} \mathrm{W}\right)$, Mesquita (2246'59” S; 43²5'56” W), Nova

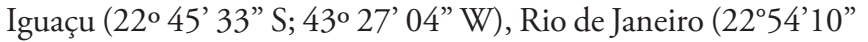
S; 4312'27" W) and São João de Meriti (2248'14" S; 4322’20" $\mathrm{W})$ (Figure 1). One hundred and ninety-seven cats that were attended at veterinary clinics between October 2011 and March 2013 were selected as a non-probability convenience sample, regardless of gender, breed or age. Blood samples were obtained aseptically by means of cephalic phlebotomy and were transferred into sterile tubes containing EDTA as anticoagulant. Data on the animals such as age ( $\leq 6$ months Vs. $>6$ months), gender (male Vs. female) and breed (mixed breed Vs. pure breed) were recorded in order to assess potential risk factors for hemoplasma infection. The samples were separated into seasons (summer, winter, fall and spring) according to their collection date. The procedures applied in this study had previously been approved by our university's ethics committee for animal use, under protocol number 23083.004088/2013-94.

\section{Hematological analysis}

Complete blood counts were carried out using a fully automated analyzer (Poch-100 iV; Roche, USA), in accordance with the manufacturer's recommendations. The hematological parameters obtained included total erythrocyte, leukocyte and platelet counts, hemoglobin concentration, packed cell volume, mean corpuscular volume and mean corpuscular hemoglobin concentration. Differential leukocyte counts and hemoplasma cytological diagnosis were performed manually on Diff Quick-stained (Laborclin, Brazil) thin blood films, using an optical microscope, with immersion objective lens magnification of 1000x (JAIN, 1993). Total plasma protein concentration was determined using a refractometry technique. After the hematological tests, the blood samples were stored at $-20^{\circ} \mathrm{C}$ until molecular analysis was performed.

\section{Molecular assays}

DNA extraction from $200 \mu \mathrm{L}$ of whole blood was performed using a Relia Prep ${ }^{\mathrm{TM}}$ Blood gDNA Miniprep System kit (Promega, Wisconsin, USA) and was eluted with $100 \mu \mathrm{L}$ of elution buffer, in accordance with to the manufacturer's instructions. Concentration and purity were determined using a NanoDrop 2000 spectrophotometer (Thermo Scientific, USA). For monitoring contaminant DNA during the process of DNA extraction, sterilized ultrapure water was used as a negative control.

Initially, DNA samples were screened for the $16 \mathrm{~S}$ rRNA gene of Mycoplasma spp., using primers previously described (KEWISH et al., 2004), by means of real-time PCR assays (Table 1). The reactions were performed using the StepOnePlus ${ }^{\mathrm{TM}}$ real-time PCR system thermocycler (Applied Biosystems, California, USA) with the following specifications: 1X Power SYBR ${ }^{\circledR}$ Green PCR Master Mix (Applied Biosystems, California, USA), 0.625 $\mu \mathrm{M}$ of each primer and $3 \mu \mathrm{L}$ of DNA template in a total volume of $12 \mu \mathrm{L}$. The protocol consisted of subjection to $95^{\circ} \mathrm{C}$ for $10 \mathrm{~min}$, followed by 40 cycles of $95^{\circ} \mathrm{C}$ for $20 \mathrm{~s}$ and $60^{\circ} \mathrm{C}$ for $1 \mathrm{~min}$. A dissociation curve was obtained to verify the amplification specificity $\left(95^{\circ} \mathrm{C} / 20 \mathrm{~s}-60^{\circ} \mathrm{C} / 70 \mathrm{~s}-95^{\circ} \mathrm{C} / 15 \mathrm{~s}\right)$. In order to differentiate Mycoplasma species, positive samples were subjected to 


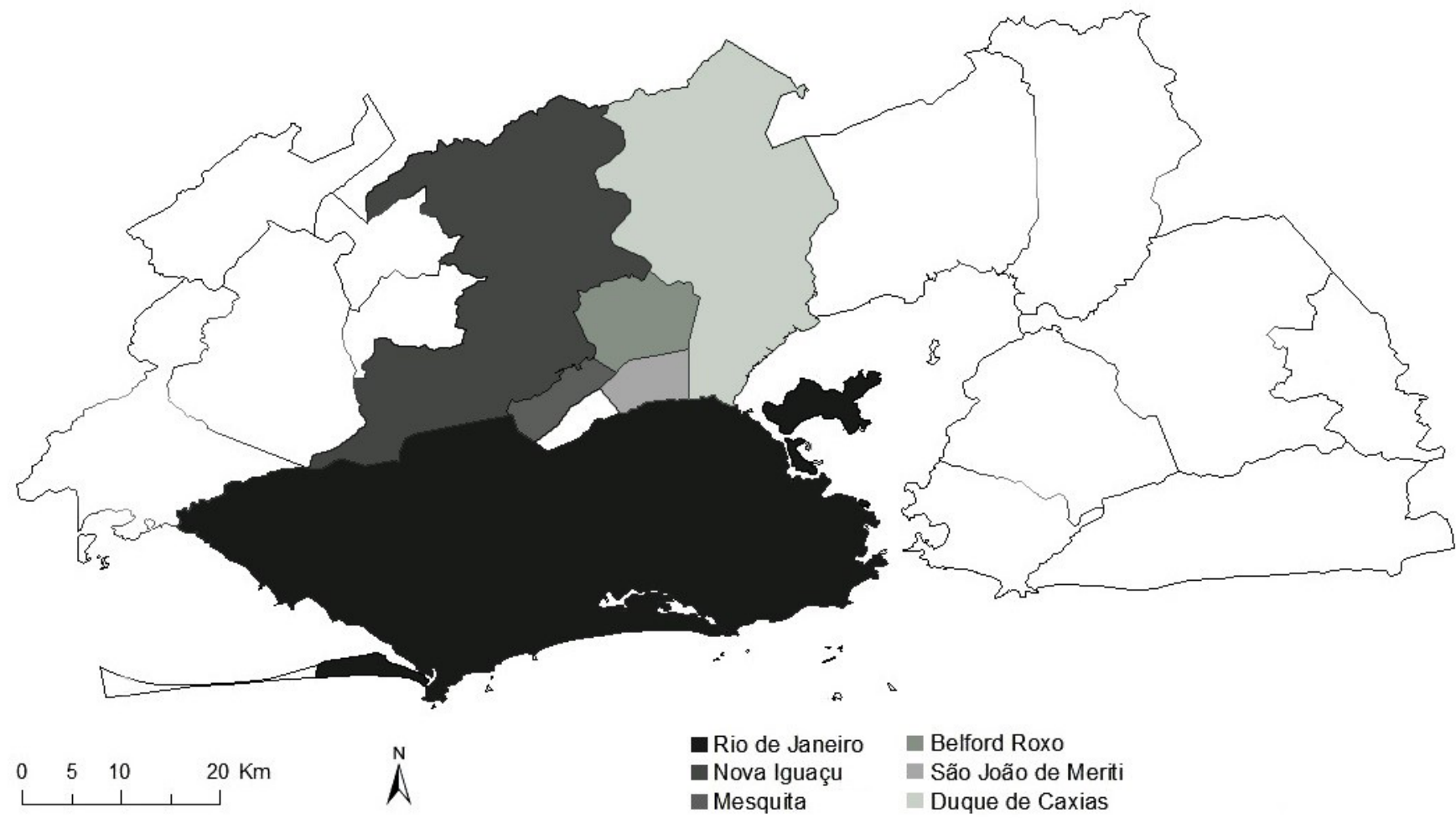

Figure 1. Geographical distribution of the sampled animal in Metropolitan area of Rio de Janeiro Brazil.

Table 1. Summary information on the different PCR primer sets used in the study.

\begin{tabular}{|c|c|c|}
\hline $\begin{array}{c}\text { Real-time PCR } \\
\text { Primer }\end{array}$ & Sequence (5'-3') & Tm \\
\hline $\begin{array}{l}\text { Mycoplasma spp. } \\
\text { Myco-F } \\
\text { Myco-R }\end{array}$ & $\begin{array}{l}\text { ACGAAAGTCTGATGGAGCAATA } \\
\text { ACGCCCAATAAATCCGRATAAT }\end{array}$ & 77.1 \\
\hline $\begin{array}{l}\text { Conventional } \\
\text { PCR Primers }\end{array}$ & Sequence $\left(5^{\prime}-3^{\prime}\right)$ & bp \\
\hline $\begin{array}{l}\text { Mhf } \\
\text { Hfelis-fl } \\
\text { Hfelis-r3 }\end{array}$ & $\begin{array}{c}\text { GACT TTGGTTTCGGCCAAGG } \\
\text { CGAAGTACTATCATAATTATCCCTC }\end{array}$ & 393 \\
\hline $\begin{array}{l}\text { CMhm } \\
\text { Cali-F1 } \\
\text { Cali-R1 }\end{array}$ & $\begin{array}{c}\text { GCATAATGTGTCGCAATC } \\
\text { GTTTCAACTAGTACTTTCTCCC }\end{array}$ & 192 \\
\hline $\begin{array}{l}\text { CMt } \\
\text { Mt-Fw } \\
\text { Mt2-Rv } \\
\end{array}$ & $\begin{array}{l}\text { GTATCCTCCATCAGACAGAA } \\
\text { CGCTCCATATTTAATTCCAA }\end{array}$ & 488 \\
\hline
\end{tabular}

conventional PCR using specific primers (Table 1) and conditions that had previously been described for $M$. haemofelis (BERENT et al., 1998), 'Candidatus M. haemominutum' (FOLEY et al., 1998) and 'Candidatus M. turicensis' (SANTOS et al., 2009). Following amplification, the reaction products were subjected to electrophoresis on $1.5 \%$ agarose gel and were stained with ethidium bromide. The presence of DNA fragments was verified under an ultraviolet transilluminator (L-PIX Touch; Loccus Biotecnologia, Cotia, São Paulo, Brazil). In order to prevent PCR contamination, DNA extraction, reaction setup, PCR amplification and electrophoresis were performed in separated rooms.

Genomic blood DNA from naturally infected Mhf, CMhm and CMt cats used as positive control in all the PCR runs were provided by Dr. Rosangela Zacarias Machado, of the Immunoparasitology Laboratory, Department of Veterinary Pathology, UNESP, Jaboticabal. All PCR runs were performed with nuclease-free water (Invitrogen, USA) as negative control.

The analytical sensitivity and efficiency of qPCR was evaluated by using serial decimal dilutions of the qPCR target produced from the amplification of a region of $16 \mathrm{~S}$ rRNA gene with the primers HBT-F and HBT-R (CRIADO-FORNELIO et al., 2003). DNA concentration was verified using the Qubit ${ }^{\oplus}$ Fluorometer. The copy number of $16 \mathrm{~S}$ rRNA gene fragment versus Cq values were plotted to determine the analytical sensitivity of the qPCR. The linear regression, along with the determination coefficient $\left(\mathrm{R}^{2}\right)$ formed after determination of each point of the curve, can be used to evaluate whether the qPCR assay has been optimized. Each reaction's efficiency was determined considering the slope of standard curve using the following formula: [Efficiency $\left.=10^{(-1 / \text { slope })}-1\right]$

\section{Statistical analysis}

Positivity for Mycoplasma haemofelis, 'Candidatus Mycoplasma haemominutum' and 'Candidatus Mycoplasma turicensis' was correlated with associated factors and season, using the chi-square test and Fisher's exact test at the 5\% significance level. Additionally, frequencies of hematological abnormalities as anemia (PCV $<24 \%$; 
hemoglobin $<8.0 \mathrm{~g} / \mathrm{dL}$ and erythrocytes $<5.0 \times 10^{6}$ cells $/ \mu \mathrm{l}$ ), thrombocytopenia (platelets count $<300 \times 10^{3} \mathrm{cells} / \mu \mathrm{l}$ ), lymphocytosis (lymphocytes count $>7.0 \times 10^{3}$ cells $/ \mu \mathrm{l}$ ), monocytosis (monocytes count $>0.85 \times 10^{3}$ cells $/ \mu \mathrm{l}$ ) and, activated monocytes were correlated with Mhf positivity. The results were compared to reference intervals established by Jain (1993).

The agreement between cytological diagnosis and real-time PCR regarding hemoplasma diagnoses was evaluated by means of the kappa test. Hematological analyses were evaluated through the Lilliefors normality test, followed by analysis of variance (ANOVA) or the Mann-Whitney test at the 5\% significance level. All of these statistical tests were performed using the Bioestat 5.0 statistical software.

\section{Results}

The detection limit of the qPCR was 10 copies of Mycoplasma sp $16 \mathrm{~S}$ rRNA gene. The determination coefficient $\left(\mathrm{R}^{2}\right)$ of the six dilutions tested in the standard curve was $99 \%$, with Cq ranging from $22.31 \pm 0.13$ cycles in the first dilution $\left(1 \times 10^{6}\right.$ copies of $16 \mathrm{~S}$ rRNA gene) to $39.47 \pm 0.27$ cycles in the last dilution (10 copies of $16 \mathrm{~S}$ rRNA gene). The reaction's efficiency was $96.47 \%$.

Out of the 197 cats sampled, 22 (11.2\%) presented structures compatible with hemoplasma organisms on blood smears. On the other hand, 45 (22.8\%) were positive for Mycoplasma spp. by means of $16 \mathrm{~S}$ rRNA gene real-time PCR. The frequency of hemoplasma species was 4.6\% (9/197) for Mycoplasma haemofelis and 'Candidatus Mycoplasma turicensis' and 11.7\% (23/197) for 'Candidatus Mycoplasma haemominutum'. Two cats (1\%) were positive for both CMhm and Mhf whereas coinfection of $\mathrm{CMhm} / \mathrm{CMt}, \mathrm{CMt} / \mathrm{Mhf}$ and CMhm/CMt/Mhf was observed in only one cat each (0.5\%). Comparing the blood smear and real-time PCR diagnostic tools, only seven animals were positive through both techniques, which corresponded to a positivity rate of $15.6 \%$ in the molecular assay. Using the kappa statistical test, the degree of agreement was 0.07 .

The numbers of cats sampled per season were 39 in the summer, 18 in the winter, 104 in the spring and 36 in the fall. The frequency of hemoplasma occurrence was seen to vary between

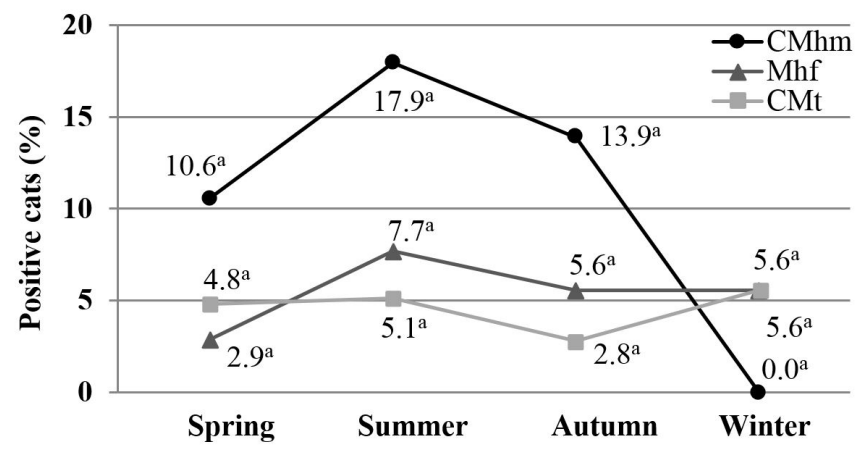

Figure 2. Distribution of Mycoplasma haemofelis (Mhf) 'Candidatus Mycoplasma haemominutum' (CMhm) and 'Candidatus Mycoplasma turicensis' (CMt) positivity during seasons. Same letters means there was no difference by Fisher's exact test at 5\% significance. the seasons. During the summer, there was higher occurrence of $M$. haemofelis (7.7\%) and 'Candidatus M. haemominutum' $(17.9 \%)(p>0.05)$. This pattern of occurrence was not observed for 'Candidatus M. turicensis' (Figure 2).

Regarding hematological findings, most of the cats that were positive for $M$. haemofelis were anemic (6/9). Lymphocytosis $(\mathrm{p}<0.03)$, thrombocytopenia $(\mathrm{p}<0.04)$ and presence of activated monocytes in blood smears $(\mathrm{p}<0.04)$ were statistically associated with Mhf positivity (Table 2 and 3). On the other hand, no hematological changes were shown by CMhm and CMt-positive cats $(\mathrm{p}>0.05)$ (Table 2).

With regard to associated factors, male cats were more likely to be positive for Mhf and CMhm than were female cats $(\mathrm{p}<0.01)$. However, taking into account CMt positivity, male and female cats showed similar chances of being positive. There was no statistical correlation for age or breed (Table 4).

\section{Discussion}

In this study, we investigated hematological disorders resulting from infection by hemoplasma species in cats that were attended at veterinary clinics in Rio de Janeiro. Over recent years, the cat population has shown a marked increase because of the ease of handling cats, with regard to cost and space requirements. Thus, studies investigating diseases that affect cats and the risk of transmission of pathogens to humans are necessary.

The concordance $(\kappa=0.07)$ observed between real time PCR frequencies (22.8\%) and cytological diagnosis (11.2\%) was considered low (ROSNER, 2006). A previous survey conducted in Sáo Paulo, Brazil, also demonstrated a distinction between these techniques when used for diagnosing hemotropic mycoplasmas in cats (HORA, 2008). Until recently, diagnoses of hemoplasma infection were commonly based on cytological identification of organisms on the surface of red blood cells. However, the specificity and sensitivity of this method for hemoplasma detection is low, with the possibility of false positive and negative results (HARVEY, 2006; WILLI et al., 2007; SYKES, 2010). Because of the many limitations of this technique, PCR has become the preferred test for making diagnoses of hemoplasma, mainly based on hemoplasma detection in the asymptomatic cat population (SYKES, 2010; TASKER, 2010; BARKER \& TASKER, 2013).

The frequency of feline hemoplasma species found was similar to that found in client-owned cats, blood donor cats and unhealthy non-anemic cats (GENTILINI et al., 2009; MAHER et al., 2010; SANTOS et al., 2014; DUARTE et al., 2015). However, higher or lower rates of hemoplasma infection have been reported, depending on the diagnostic technique, geographical location and population studied. 'Candidatus M. haemominutum' (11.7\%) was the species most commonly detected in the cats of this study and in other studies (LAPPIN et al., 2006; GENTILINI et al., 2009; SANTOS et al., 2014). However, Mycoplasma species predominance can vary depending on the degree of pathogenicity among them as well as differences in the cat populations studied. For instance, $M$. haemofelis has been the hemoplasma species most commonly observed in anemic or sick cat populations (CRIADO-FORNELIO et al., 2003; KEWISH et al., 2004; WILLI et al., 2006; HORA, 


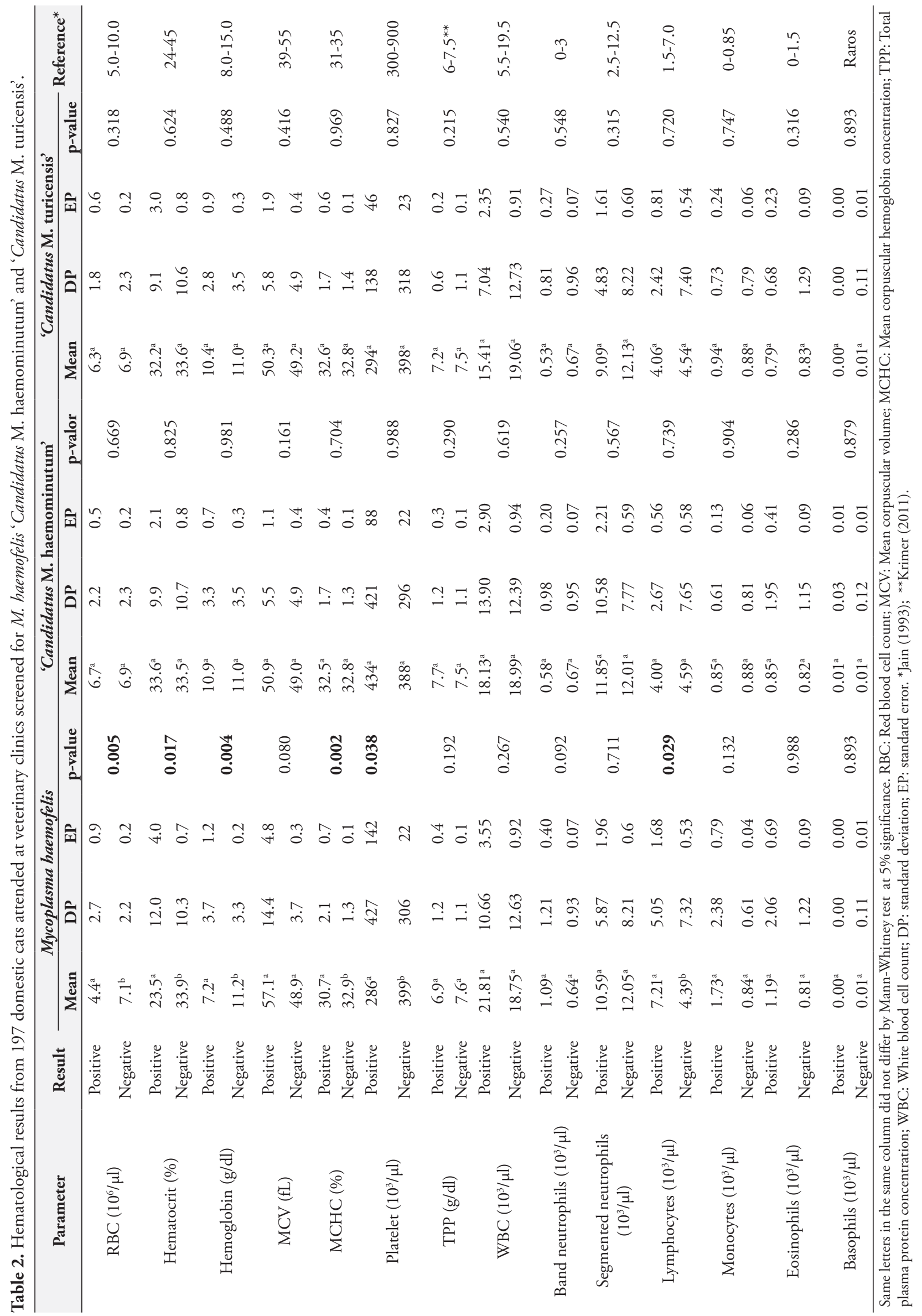


Table 3. Hematological results for Mycoplasma haemofelis from 197 domestic cats attended at veterinary clinics in Rio de Janeiro Brazil.

\begin{tabular}{|c|c|c|c|c|}
\hline \multirow{2}{*}{\multicolumn{2}{|c|}{ Hematological change }} & \multicolumn{2}{|c|}{$\begin{array}{c}\text { Mycoplasma } \\
\text { haemofelis } \mathrm{n}(\%)\end{array}$} & \multirow{2}{*}{ p-value } \\
\hline & & $\begin{array}{c}\text { Positive } \\
(n=9)\end{array}$ & $\begin{array}{l}\text { Negative } \\
(n=188)\end{array}$ & \\
\hline \multirow{2}{*}{$\begin{array}{l}\text { Anemia } \\
\text { (RBC Ht Hg) }\end{array}$} & Yes & $6(16.2)^{a}$ & $31(83.8)$ & \multirow{2}{*}{0.0017} \\
\hline & No & $3(1.9)^{\mathrm{b}}$ & $157(98.1)$ & \\
\hline \multirow{2}{*}{ Thrombocytopenia } & Yes & $8(7.8)^{\mathrm{a}}$ & $95(92.2)$ & \multirow{2}{*}{0.0365} \\
\hline & No & $1(1.1)^{b}$ & $93(98.9)$ & \\
\hline \multirow{2}{*}{ Lymphocytosis } & Yes & $4(14.8)^{a}$ & $23(85.2)$ & \multirow{2}{*}{0.0220} \\
\hline & No & $5(2.9)^{\mathrm{b}}$ & $165(97.1)$ & \\
\hline \multirow{2}{*}{ Monocytosis } & Yes & $5(6.0)^{a}$ & $79(94.0)$ & \multirow{2}{*}{0.5000} \\
\hline & No & $4(3.5)^{\mathrm{a}}$ & $109(96.5)$ & \\
\hline \multirow{2}{*}{ MAM } & Yes & $5(11.1)^{\mathrm{a}}$ & $40(88.9)$ & \multirow{2}{*}{0.0306} \\
\hline & No & $4(2.6)^{b}$ & $148(97.4)$ & \\
\hline
\end{tabular}

Same letters in the same column did not differ by Fisher's exact test at $5 \%$ significance. RBC: Red blood cell count; Ht: Hematocrit; Hg: hemoglobin; MCV: Mean corpuscular volume; MCHC: Mean corpuscular hemoglobin concentration; MAM: activated monocytes.

2008). Double and triple copositivity was noted in our study. Occurrences of concurrent infection with two or more hemoplasma species are not common in the literature, such that this has only been found in a low percentage of cats or has even been absent (MACIEIRA et al., 2008; ARAGĀO-DE-SOUSA et al., 2013; SPADA et al., 2014). The present study provided the first report of triple coinfection in a cat in Rio de Janeiro and, interestingly, this cat did not show any hematological abnormality. This finding emphasizes the importance of asymptomatic and chronic carriers in maintaining bacterial circulation.

Regarding seasonal influence, the highest numbers of M. haemofelis and 'Candidatus M. haemominutum' PCR-positive cats were reported in the summer. On the other hand, 'Candidatus M. turicensis' showed peak infection during the winter. Although Mhf (7.7\%) and CMhm (17.9\%) infections occurred more frequently during summer months, hemoplasma infections seem to be uniformly distributed throughout the year. In our point of view, this infection pattern probably results from the active season for fleas in Rio de Janeiro, where the temperatures remain moderate throughout the year.

Epidemiological studies on the seasonal distribution of Mycoplasma spp. are scarce. In a recent study in Italy, no correlation between hemoplasma infection rate and season was also demonstrated, but higher frequency of hemoplasmas was observed in the spring (SPADA et al., 2014). On the other hand, another author found higher prevalence in the summer than in the fall in Italy (GENTILINI et al., 2009), what is in accordance to the hypothesis that hemoplasmas can be transmitted to cats by arthropod vectors. The flea Ctenocephalides felis is the main ectoparasite incriminated in transmission of hemotropic hemoplasmas among cats worldwide, especially because it is the ectoparasite most commonly found parasitizing these animals (SHAW et al., 2004; LAPPIN et al.,
2006; MENDES-DE-ALMEIDA et al., 2007). DNA samples of 'Candidatus M. haemominutum', $M$. haemofelis and 'Candidatus M. turicensis' have been found in fleas and their feces (SHAW et al., 2004; WOODS et al., 2005; LAPPIN et al., 2006; HORNOK et al., 2010; ASSARASAKORN et al., 2012). Mhf and CMhm DNA was also found in ticks (FYUMAGWA et al., 2008). However, transmission via blood-feeding arthropods in these hosts is not yet fully proven and elucidated (WOODS et al., 2005; WILLI et al., 2007; TASKER, 2010).

Regarding hematological abnormalities, anemia was observed in $66.7 \%$ of the $M$. haemofelis PCR-positive cats, which is a common finding in hemoplasma infection, especially in cases with M. haemofelis (HARVEY, 2006). An association between anemia and $M$. haemofelis infection has also been observed in previous studies, which corroborates our results (KEWISH et al., 2004; HORA, 2008; LOBETTI \& LAPPIN, 2012). M. haemofelis has also been incriminated as the most prevalent hemoplasma species in cats with clinical suspicion of feline mycoplasmosis (CRIADO-FORNELIO et al., 2003). These observations demonstrate the pathogenic potential of this particular hemoplasma. On the other hand, other studies have not reported any correlation between anemia and infection by this hemoplasma species (WILLI et al., 2006; MACIEIRA et al., 2008).

Although it has been reported that abnormal leukocyte and platelet counts are not consistent with hemoplasma infections (BRADDOCK et al., 2004; SYKES, 2010), presence of lymphocytosis, thrombocytopenia and activated monocytes were statistically related to infection by $M$. haemofelis in the present study. The association between thrombocytopenia and positivity for this hemoplasma species has already been demonstrated (HORA, 2008; LOBETTI \& LAPPIN, 2012). However, no such change was observed in any of the blood counts performed over a 30-day period of monitoring that was conducted on cats naturally infected by $M$. haemofelis (BRADDOCK et al., 2004). Although monocytosis was frequently observed among Mhf positive cats, it was not statistically associated with infection, in contrast to the observations of Vergara et al. (2016). On the other hand, activated monocytes were observed frequently in blood smears and were consistently associated with Mhf positivity in our study. It has been reported that the presence of activated monocytes, monocytosis, and erythrophagocytosis are common in the acute phase of infection (HARVEY, 2006)

Cats parasitized only by 'Candidatus M. haemominutum' or 'Candidatus M. turicensis' presented mild to moderate anemia, with hematocrit ranging from $16 \%$ to $21 \%$. Severe anemia (hematocrit $<13 \%$ ) was only observed in cats showing copositivity for both M. haemofelis and 'Candidatus M. haemominutum'. Normocytic normochromic non-regenerative anemia was found in cats that were positive for these hemoplasma species. However, no hematological alteration, including anemia, was associated with positivity for 'Candidatus M. haemominutum' alone or for 'Candidatus M. turicensis'. This, in association with the laboratory findings regarding infection by $M$. haemofelis confirmed the distinct pathogenicity of the hemotropic mycoplasma species described in the literature, in which 'Candidatus M. haemominutum' and 'Candidatus M. turicensis' are considered to be less pathogenic species (FOLEY et al., 1998; HARVEY, 2006; TASKER, 2010; 
Table 4. Statistical analysis of factors associated with Mycoplasma haemofelis 'Candidatus Mycoplasma haemominutum' and 'Candidatus Mycoplasma turicensis' positivity in domestic cats attended at veterinary clinics in Rio de Janeiro Brazil.

\begin{tabular}{|c|c|c|c|c|c|}
\hline & Cats (n) & Positive cats n/(\%) & p-valor & Odds Ratio & $95 \% \mathrm{CI}$ \\
\hline \multicolumn{6}{|l|}{ M. haemofelis } \\
\hline \multicolumn{6}{|l|}{ Age } \\
\hline$\leq 6$ months & 29 & $0(0.0)^{\mathrm{a}}$ & & - & \\
\hline$>6$ months & 168 & $9(5.4)^{\mathrm{a}}$ & 0.3613 & - & - \\
\hline \multicolumn{6}{|l|}{ Gender } \\
\hline Female & 108 & $0(0.0)^{\mathrm{a}}$ & & - & \\
\hline Male & 89 & $9(10.1)^{b}$ & 0.0006 & - & - \\
\hline \multicolumn{6}{|l|}{ Breed } \\
\hline Mixed breed & 173 & $7(4.0)^{\mathrm{a}}$ & & 1 & \\
\hline Pure breed & 24 & $2(8.3)^{a}$ & 0.2997 & 2.15 & $0.42-11.04$ \\
\hline \multicolumn{6}{|l|}{ Season } \\
\hline Winter & 18 & $1(5.6)^{\mathrm{a}}$ & 0.4665 & 1.98 & $0.19-20.17$ \\
\hline Spring & 104 & $3(2.9)^{a}$ & & 1 & - \\
\hline Summer & 39 & $3(7.7)^{a}$ & 0.3451 & 2.08 & $0.54-14.53$ \\
\hline Fall & 36 & $2(5.6)^{a}$ & 0.6021 & 1.98 & $0.31-12.35$ \\
\hline
\end{tabular}

\section{'C.M. haemominutum'}

\section{Age}

$\leq 6$ months

$>6$ months

Gender

Female

Male

\section{Breed}

Mixed breed

Pure breed

Season

Winter

Spring

Summer

Fall

\section{' $C$. M. turicensis'}

Age

$\leq 6$ months

$>6$ months

Female

Male

Breed

Mixed breed

Pure breed

Season

Winter

Spring

Summer

Fall
29

168

108

$\begin{array}{cc}29 & 1(3.4)^{\mathrm{a}} \\ 168 & 22(13.1)^{\mathrm{a}} \\ 108 & 6(5.6)^{\mathrm{a}} \\ 89 & 17(19.1)^{\mathrm{b}}\end{array}$

$89 \quad 17(19.1)^{\mathrm{b}}$

173

24

18

104

39

36

89

173

24

18

104

39

36 $19(11.0)^{\mathrm{a}}$

$4(16.7)^{\mathrm{a}}$

$0(0.0)^{\mathrm{a}}$

$11(10.6)^{\mathrm{a}}$

$7(17.9)^{\mathrm{a}}$

$5(13.9)^{a}$
0.2097

0.0065

0.4930

0.2159

0.0850

0.1567

$2(6.9)^{\mathrm{a}}$

$6(4.2)^{\mathrm{a}}$

$3(2.8)^{\mathrm{a}}$

$6(6.7)^{\mathrm{a}}$

$8(4.6)^{\mathrm{a}}$

$1(4.2)^{\mathrm{a}}$

$1(5.6)^{\mathrm{a}}$

$5(4.8)^{\mathrm{a}}$

$2(5.1)^{\mathrm{a}}$

$1(2.8)^{\mathrm{a}}$
$0.55-35.6$

$1.51-10.68$

$0.50-5.25$

1.62

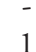

1.84

$0.66-5.17$

1.36

$0.44-4.23$

Same letters in the same column did not differ by Fisher's exact at $5 \%$ significance.

ARAGÃO-DE-SOUSA et al., 2013), such that infection with these species separately is not often associated with significant anemia. It is believed that cofactors such as retroviruses, coinfection by hemoplasmas and concomitant diseases could be involved in development and aggravation of the clinical signs (WILLI et al., 2006; MACIEIRA et al., 2008; TASKER, 2010; MARTÍNEZ-DÍAZ et al., 2013).
Regarding associated factors, positivity for $M$. haemofelis and 'Candidatus M. haemominutum' was considerably higher among male cats, and only male cats were positive for $M$. haemofelis. Additionally, 'Candidatus M. haemominutum'-positive cats were shown to be four times more likely to become infected than females. On the other hand, positivity for 'Candidatus M. turicensis' did not show any association with gender, even though males presented 
twice as much chance of infection as females. These observations can be explained by the males' behavior, such as outdoor access, especially among those that were not neutered, which might predispose them towards greater exposure to arthropod vectors and fights, thus resulting in a higher likelihood of infection (HARRUS \& BANETH, 2005; VERGARA et al., 2016). Adults and young cats as well as mixed breed and pure breed cats had similar change of becoming infected.. Although adult cats had four times more chance than younger ones of becoming infected by CMhm, this variable was not statistically significant. Corroborating our results, Hora (2008) did not observed association between age or breed with hemoplasma infection. On the other hand, several studies have reported that older cats are more likely to be infected with hemoplasmas (WILLI et al., 2006; SANTOS et al., 2014; VERGARA et al., 2016).

This study shows that three hemotropic mycoplasma species occur in the metropolitan region of Rio de Janeiro and that 'Candidatus Mycoplasma haemominutum' is the most common agent infecting this cat population. In addition, CMt was reported for the first time in cats from Rio de Janeiro. The hematological data indicates that Mycoplasma haemofelis is a relevance agent among cats population as it represents an important cause of anemia and other hematological changes.

\section{References}

Aragão-de-Sousa SKS, Sampaio-Junior FD, Sousa LO, Santos RC, Gonçalves EC, Scofield A, et al. Diagnóstico molecular da infecçáo por hemoplasmas em gatos domésticos naturalmente infectados da cidade de Belém, Pará. Pesq Vet Bras 2013; 33(9): 1116-1120. http://dx.doi. org/10.1590/S0100-736X2013000900011.

Assarasakorn S, Veir JK, Hawley JR, Brewer MM, Morris AK, Hill AE, et al. Prevalence of Bartonella species, hemoplasmas, and Rickettsia felis DNA in blood and fleas of cats in Bangkok, Thailand. Res Vet Sci 2012; 93(3): 1213-1216. PMid:22521739. http://dx.doi.org/10.1016/j. rvsc.2012.03.015.

Barker E, Tasker S. Haemoplasmas: Lessons learnt from cats. $N Z$ Vet J 2013; 61(4): 184-192. PMid:23458414. http://dx.doi.org/10.1080/00 480169.2013.771760.

Berent LM, Messick JB, Cooper SK. Detection of Haemobartonella felis in cats with experimentally induced acute and chronic infections, using a polymerase chain reaction assay. Am J Vet Res 1998; 59(10): 1215-1220. PMid:9781450.

Braddock JA, Tasker S, Malik R. The use of real-time PCR in the diagnosis and monitoring of Mycoplasma haemofelis copy number in a naturally infected cat. J Feline Med Surg 2004; 6(3): 161-165. PMid:15135353. http://dx.doi.org/10.1016/j.jfms.2003.12.004.

Criado-Fornelio A, Martinez-Marcos A, Buling-Saraña A, Barba-Carretero JC. Presence of Mycoplasma haemofelis, Mycoplasma haemominutum and piroplasmids in cats from southern Europe: a molecular study. Vet Microbiol 2003; 93(4): 307-317._PMid:12713893. http://dx.doi.org/10.1016/ S0378-1135(03)00044-0.

Duarte A, Marques V, Correia JHD, Neto I, Bráz BS, Rodrigues C, et al. Molecular detection of haemotropic Mycoplasma species in urban and rural cats from Portugal. J Feline Med Surg 2015; 17(6): 516-522. PMid:25228167. http://dx.doi.org/10.1177/1098612X14550172.
Foley JE, Harrus S, Poland A, Chomel B, Pedersen NC. Molecular clinical and pathologic comparison of two distinct strains of Haemobartonella felis in domestic cats. Am J Vet Res 1998; 59(12): 1581-1588. PMid:9858411.

Fyumagwa RD, Simmler P, Willi B, Meli ML, Sutter A, Hoare R, et al. Molecular detection of haemotropic Mycoplasma species in Rhipicephalus sanguineus tick species collected on lions (Panthera leo) from Ngorongoro Crater Tanzania. S Afr J Wildl Res 2008; 38(2): 117-122. http://dx.doi. org/10.3957/0379-4369-38.2.117.

Gentilini F, Novacco M, Turba ME, Willi B, Bacci ML, Hofmann-Lehmann R. Use of combined conventional and real-time PCR to determine the epidemiology of feline haemoplasma infections in Northern Italy. $J$ Feline Med Surg 2009; 11(4): 277-285. PMid:18790658. http://dx.doi. org/10.1016/j.jfms.2008.06.008.

Harrus S, Baneth G. Drivers for the emergence and re-emergence of vector-borne protozoal and bacterial diseases. Int I Parasitol 2005; 35(11-12): 1309-1318. PMid:16126213. http://dx.doi.org/10.1016/j. ijpara.2005.06.005.

Harvey JW. Hemotropic mycoplasmosis (hemobartonellosis). In: Greene CE. Infectious disease of the dog and cat. 3rd ed. Philadelphia: Saunders Elsevier; 2006. p. 252-260.

Hora AS. Micoplasmas hemotrópicos como potenciais agentes causadores de anemia em felinos domésticos [Thesis]. São Paulo: Universidade de São Paulo; 2008.

Hornok S, Meli ML, Perreten A, Farkas R, Willi B, Beugnet F, et al. Molecular investigation of hard ticks (Acari: Ixodidae) and fleas (Siphonaptera: Pulicidae) as potential vectors of rickettsial and mycoplasmal agents. Vet Microbiol 2010; 140(1-2): 98-104. PMid:19660880. http://dx.doi. org/10.1016/j.vetmic.2009.07.013.

Hu Z, Yin J, Shen K, Kang W, Chen Q. Outbreaks of hemotrophic mycoplasma infections in China. Emerg Infect Dis 2009; 15(7): 11391140. PMid:19624945. http://dx.doi.org/10.3201/eid1507.090174.

Jain NC. Essentials of veterinary hematology. Philadelphia: Lea \& Febiger; 1993.

Kewish KE, Appleyard GD, Myers SL, Kidney BA, Jackson ML. Mycoplasma haemofelis and Mycoplasma haemominutum detection by polymerase chain reaction in cats from Saskatchewan and Alberta. Can Vet J 2004; 45(9): 749-752. PMid:15510683.

Krimer PM. Generating and interpreting test results: test validity quality control reference values and basic epidemiology. In: Latimer KS. Duncan \& Prasses: veterinary laboratory medicine clinical pathology. 5th ed. Blackwell Publishing; 2011. p. 365-382.

Lappin MR, Griffin B, Brunt J, Riley A, Burney D, Hawley J, et al. Prevalence of Bartonella species haemoplasma species Ehrlichia species Anaplasma phagocytophilum and Neorickettsia risticii DNA in the blood of cats and their fleas in the United States. J Feline Med Surg 2006; 8(2): 85-90. PMid:16290092. http://dx.doi.org/10.1016/j.jfms.2005.08.003.

Lobetti R Lappin MR. Prevalence of Toxoplasma gondii, Bartonella species and haemoplasma infection in cats in South Africa. J Feline Med Surg 2012; 14(12): 857-862. PMid:22729571. http://dx.doi. org/10.1177/1098612X12452495.

Macieira DB, Menezes RCAA, Damico CB, Almosny NR, McLane HL, Daggy JK, et al. Prevalence and risk factors for hemoplasmas in domestic cats naturally infected with feline immunodeficiency virus and/or feline leukemia virus in Rio de Janeiro - Brazil. J Feline Med Surg 2008; 10(2): 120-129. PMid:17905624. http://dx.doi.org/10.1016/j.jfms.2007.08.002. 
Maggi RG, Mascarelli PE, Havenga LN, Naidoo V, Breitschwerdt EB. Co-infection with Anaplasma platys, Bartonella henselae and 'Candidatus Mycoplasma haematoparvum' in a veterinarian. Parasit Vectors 2013; 6(1): 103. PMid:23587235. http://dx.doi.org/10.1186/1756-3305-6-103.

Maher IE, Tasker S, Polizopoulou Z, Dasopoulou A, Egan K, Helps $\mathrm{CR}$, et al. Polymerase chain reaction survey of feline haemoplasma infections in Greece. J Feline Med Surg 2010; 12(8): 601-605. PMid:20580298. http://dx.doi.org/10.1016/j.jfms.2010.02.004.

Martínez-Díaz VL, Silvestre-Ferreira AC, Vilhena H, Pastor J, Francino $\mathrm{O}$, Altet L. Prevalence and co-infection of haemotropic mycoplasmas in Portuguese cats by real-time polymerase chain reaction. J Feline Med Surg 2013; 15(10): 879-885. PMid:23482254. http://dx.doi. org/10.1177/1098612X13480985.

Mendes-de-Almeida F, Labarthe N, Guerrero J, Faria MC, Branco AS, Pereira CD, et al. Follow-up of the health conditions of an urban colony of free-roaming cats (Felis catus Linnaeus, 1758) in the city of Rio de Janeiro Brazil. Vet Parasitol 2007; 147(1-2): 9-15. PMid:17481822. http://dx.doi.org/10.1016/j.vetpar.2007.03.035.

Rosner B. Fundamentals of biostatistics. 6th ed. Boston: Duxbury Press; 2006.

Santos AP, Conrado FO, Messick JB, Biondo AW, Oliveira ST, Guimarães AM, et al. Hemoplasma prevalence and hematological abnormalities associated with infection in three different cat populations from Southern Brazil. Rev Bras Parasitol Vet 2014; 23(4): 428-434. PMid:25517519. http://dx.doi.org/10.1590/S1984-29612014079.

Santos AP, Messick JB, Biondo AW, Oliveira ST, Pedralli V, Lasta CS, et al. Design optimization and application of a conventional PCR assay with an internal control for control of 'Candidatus Mycoplasma turicensis' $16 \mathrm{~S}$ rDNA in domestic cats from Brazil. Vet Clin Pathol 2009; 38(4): 443-452. PMid:19548972. http://dx.doi.org/10.1111/j.1939-165X.2009.00158.x.

Shaw SE, Kenny MJ, Tasker S, Birtles RJ. Pathogen carriage by the cat flea Ctenocephalides felis (Bouché) in the United Kingdom. Vet Microbiol 2004; 102(3-4): 183-188. PMid:15327793. http://dx.doi.org/10.1016/j. vetmic.2004.06.013.

Spada E, Proverbio D, Galluzzo P, Della Pepa A, Bagnagatti De Giorgi G, Perego R, et al. Prevalence of haemoplasma infections in stray cats in Northern Italy. ISRN Microbiol 2014; 2014: 1-8. http://dx.doi. org/10.1155/2014/298352.
Sykes JE. Feline hemotropic mycoplasmas. J Vet Emerg Crit Care 2010; 20(1): 62-69. PMid:20230435. http://dx.doi.org/10.1111/j.14764431.2009.00491.x.

Tasker S. Current concepts in feline haemobartonellosis. In Practice 2006; 28(3): 136-141. http://dx.doi.org/10.1136/inpract.28.3.136.

Tasker S. Haemotropic mycoplasmas: what's their real significance in cats? J Feline Med Surg 2010; 12(5): 369-381. PMid:20417898. http:// dx.doi.org/10.1016/j.jfms.2010.03.011.

Vergara RW, Galleguillos FM, Jaramillo MG, Almosny NRP, Martínez PA, Behne PG, et al. Prevalence risk factor analysis and hematological findings of hemoplasma infection in domestic cats from Valdivia Southern Chile. Comp Immunol Microbiol Infect Dis 2016; 46: 20-26. PMid:27260806. http://dx.doi.org/10.1016/j.cimid.2016.03.004.

Villiers E. Disorders of eryrhrocytes. In: Villiers E, Blackwood L. BSAVA Manual of canine and feline clinical pathology. 2nd ed. Gloucester: British Small Animal Veterinary Association; 2005. p. 44-45.

Wengi N, Willi B, Boretti FS, Cattori V, Riond B, Meli ML, et al. Realtime PCR-based prevalence study, infection follow-up and molecular characterization of canine hemotropic mycoplasmas. Vet Microbiol 2008; 126(1-3): 132-141. PMid:17656047. http://dx.doi.org/10.1016/j. vetmic.2007.06.018.

Willi B, Boretti FS, Baumgartner C, Tasker S, Wenger B, Cattori V, et al. Prevalence, risk factor analysis, and follow-up of infections caused by three feline hemoplasma species in cats in Switzerland. J Clin Microbiol 2006; 44(3): 961-969. PMid:16517884. http://dx.doi.org/10.1128/ JCM.44.3.961-969.2006.

Willi B, Boretti FS, Tasker S, Meli ML, Wengi N, Reusch CE, et al. From Haemobartonella to hemoplasma: molecular methods provide new insights. Vet Microbiol 2007; 125(3-4): 197-209. PMid:17706380. http://dx.doi.org/10.1016/j.vetmic.2007.06.027.

Woods JE, Brewer MM, Hawley JR, Wisnewski N, Lappin MR. Evaluation of experimental transmission of Candidatus Mycoplasma haemominutum and Mycoplasma haemofelis by Ctenocephalides felis to cats. Am J Vet Res 2005; 66(6): 1008-1012. PMid:16008224. http://dx.doi.org/10.2460/ ajvr.2005.66.1008. 